\title{
Library and Information Science Literacy in India: History- Development, Growth and Present Status of LIS Literacy in India
}

\author{
Raj Kumar Sharma \\ Assistant Librarian, Rayat Polytechnic College, Rayat Group of Institutions \\ (Ropar Campus), Railmajra SBS Nagar, Punjab, India
}

\begin{abstract}
Educational Development of Library and Information Science education in India, when Maharaja of Baroda invited an American librarian to set up public libraries in the state after independence, Library Associations in the country continued with the efforts for the development of Library and Information Science education in India. The discipline got recognition with the introduction of many courses at the university level. It has seen periods of growth and maturation. It is time for Introspection and a need to know the present status of LIS and areas that need improvement.
\end{abstract}

Keywords: LIS education in India, Growth and Development, Levels of LIS education, Library Science Institutes in India, Present Status of LIS education

\section{INTRODUCTION}

The beginning of the 20th century marked the beginning of LIS education in India. There is a vast literature crediting Sayyaji Rao Gaekwad, the then Maharaja of the erstwhile princely State of Baroda, for initiating the LIS education movement in the country. American librarians, William Alanson Borden and Asa Don Dickinson were the first LIS teachers in India. John MacFarlane, an Englishman, who happened to bethe first librarian of the Imperial Library (now National Library, Kolkota) also, shares the credit for training librarians in our country. In fact, MacFarlane's trainingprogramme is the first case of LIS education in India reported in literature. It took place between 1901 and1906 in the Imperial Library when training programmeswere organized for its staff. Later it was extended to librarians working in Calcutta as well as in other states. It is believed that there was an existence of some training in library routines for the staff of university libraries prior to that also

Library Science first training course in India was established in 1911at the Central Library, Baroda at Punjab University by W. A. Borden and by A. D. Dickinson 1915. Library schools ware started by universities and library associations.

Madras Library Association and Bengal Library Association Started a certificate courses in 1929 and 1935. Universities such as Andhra University (1935), Banaras Hindu University (1941) and University of Delhi (1947). Postgraduate courses also started by universities M.Phil courses in 1977. Started by University of Delhi It was the first institution to providing facilities for research leading to doctorate degrees

Many universities have introduced correspondence courses at various levels teaching courses, of education This provides facilities to library personnel working at the lower level to improve their qualifications and update their limited knowledge and skills and also to those who could not get admission to formal courses Earlier Library Science has almost been recognized as an established disciplines now at par with other social sciences courses in the university education system.
Andhra Desa Library Association course:

Course was started in 1920 and was the first library training course started by a library association at Vijayawada. Syllabus of the course was modified to include more subjects on library work in 1934.

Mysore State (Karnataka State):

a training course for librarians and library Workers were started in Karnataka. in the year 1920. The training was conducted in Bangalore Under the programme of 'Library Development' initiated by Sir.M.Visveswaraya, the then Dewan of Mysore.

MALA - Madras library Association:

Through the effort of Dr. S.R. Ranganathan, conducted an annual summer course in Librarianship in 1929 and 1930. By the Madras Library Association, this came into existence in 1928. This programme was taken over by Madras University and was conducted as a certificate course for three months duration in 1931.

Imperial Library Course of Calcutta:

The Punjab Library School started a regular full time Diploma course in librarianship at the imperial library, now called the National Library of India, Calcutta, where he was librarian for nearly two decades. This course was planned after the Punjab University course. There was a close cooperation between these two courses. Punjab University offered course every alternative year, when the Imperial Library course was not in session from 1944 to 1946. However, the course was offered every year and finally discontinued in 1947.

\section{Bengal Library Association Course:}

the Bengal Library Association and the Association arranged for a library training camp at Bansberia under the auspices of the Hoogly District Library association. The Bengal Library Association started a regular certificate course in librarianship in 1937 which continued for a long period. 


\section{Banaras Hindu University:}

This University started diploma course at the post graduate Level in the year 1942 with complete syllabus designed from the point of handling responsibilities in Library management as well as, systematic preservation of documents and rendering of professional services

\section{Bombay University-:}

In 1944 Bombay University started diploma. these courses was for the candidates who have Passed matriculation. and who have completed graduation. The response for these courses was said to be highly positive and quite a number of library workers and fresh students got their education from Bombay University during 1940s.

\section{Calcutta University:}

West Bengal started diploma course in Library science in the year 1945 by Calcutta University. Thus, before independence there were five universities which had provision for the diploma course in library science in their academic programmes. The diploma course started by the university in 1945 attracted people from other disciplines and emphasized more on the training aspects of document presser vation and library management.

\section{Delhi University:}

one-year post-graduate Diploma in library science started in the first Department of library science few weeks before the dawn of Independence on August 15, 1947 was at the University of Delhi. This Department was started as a result of the efforts of Late. Dr.S.R Ranganathan and Late professor S.D. Gupta, Sir. Manrice Gwyer, the then Vice - Chancellor of the University had deep faith in the usefulness of libraries and library education, provided necessary infrastructure to start of library science at the University of Delhi. Dr. Ranganathan functioned as full-time honorary professor in the Department During the period 1947-1955 and professor S.D. Gupta was the Head of the Department for almost 15 years.52 this was the first Department of library science in the country which continued as a teaching department like other teaching departments in the university set up. In addition to the usual one-year post-graduate diploma course the advance course leading to the award of the master of library science (M.Lib.Sc.) degree was started in 1948.In addition to these two courses provision was also made in 1948 for the conduct of research programmes leading to the award of Ph.D. degree in 1948. After Ranganathan departure in 1955, the department was unable to offer M.Lib.Sc. Course during 1956-58.The M.Lib.Sc. Course was however again reviewed in 1959and till 1968, this was the only department in the country conducting the M.Lib.Sc courses a full time course. During the Period of Ranganathan's stay in the university one student, Dr.D.B. Krishna Rao completed his work For PhD in 1955

Library Science Institutes during 1958-64: New department was established between 1948 and 1955. During the period 1956 in Indian University environment, to1959 6 new library science departments came into existence.

\footnotetext{
$>$ Aligarh Muslim University

$>$ Maharaja Sayyaji Rao University

$>$ Nagpur University

$>$ Osmania University

$>$ Vikram University

$>$ Poona University
}

Polytechnic Diploma in Library Science: The Government polytechnics for women started offering diploma in Library science course. Polytechnics of these cities started courses during late1960s. Library and Information Science education is imparted through more than 118 universities and institutions Presently in India A total of 105 universities provide Bachelor of Library and Information Science courses, Approximate 80 universities provide the Master of Library and Information Science courses, 21 are offering two-year integrated courses, 16 universities provide M.Phil in Library and Information Science, 46 universities provide $\mathrm{PhD}$ in Library and Information Science and 2 Universities provide D.Litt Degree. Besides this, the National Institute of Science Communication and Information Resources (NISCAIR) which was earlier known as the Indian National Scientific Documentation Centre (INSDOC), New Delhi, and Documentation Research and Training Centre (DRTC), Bangalore, provide associate ship courses in Information Science, which are equivalent to the MLIS degree. Presently the subsequent LIS courses are out there in India:-

$>$ C.Lib.Sc.(Certificate course in Library and Information Science)

D.Lib.Sc.(Diploma in Library and Information Science)

$>$ B.Lib.Sc.(BLIS (Bachelor Degree in Library and Information Science)

$\rightarrow$ M.Lib.Sc. (MLIS (Master Degree in Library and In formation Science)

> PGDLAN (Post Graduate Diploma in Library Automation and Networking)

M.Phil (Master of Philosophy) in Library and Information Science

$\mathrm{PhD}$ (Doctor of Philosophy) in Library and Information Science

$>$ D.Litt in Library and Information Science

64 Affiliated to university's library schools and colleges, library science course started in 1960's.

$>$ They are enlisted here below.

Annamalai University, Cert. In Lib.Sc. 1962-66

> Burdwan University, B.Lib.Sc 1965

$>$ Gauhati University, B.Lib.Sc 1966

$>$ Gujarat University,B.Lib.Sc 1965

$>$ Jadavpur University, B.Lib.Sc 1965

> Karnataka University, Dip.Lib.Sc 1962-65

$>$ Kerala University, B.Lib.Sc 1961

$>$ Kurukshetra University, B.Lib.Sc 1969

$>$ Maratha wad University, B.Lib.Sc 1967

$>$.Mysore University, B.Lib.Sc 1965

> Punjab University, Dip. in Lib.Sc. Post Graduate 1960-68

> Punjabi University, Cert. In Lib.Sc. 1960, B.Lib.Sc 1961

> Rajasthan University Cert. In Lib.Sc. 1960, B.Lib.Sc 1961

$>$ SNDT Women's University B.Lib.Sc. 1964

> Shivaji University Dip.Lib.Sc. (Post Graduate) 1965-68 B.Lib.Sc 1968.

> Varanasi Sanskrit Vishwa vidyalaya B.Lib.Sc 1967.

$>$ APS University - B. Lib. Sc.- 1968.

> Jiwaji-University B. Lib.Sc. 1964. 
Colleges which started Library Science Course

$>$ M.L.B. Arts and Commerce College - Gwalior, B.Lib.Sc 1962.

$>$ Isbella Thoburn College - Lakhnao, UP, B.Lib.Sc 1962.

$>$ Thakur Rammat Singh College-Rewa B.Lib.Sc 1968.

$>$ Army Education Corps College- Panchmarhi, B.Lib.Sc 1962-64.

\section{During 1970-80 Library and Information Science Education}

In the year 1970-80,s the education programmes started receiving global attention. The establishment of international co-operative information systems likes INIS, AGRIS and DEVIS under the umbrella of UNISIST philosophy was a clean indicator to this fact. This shifted the emphasis of library and information science profession from national level to that of international level. The status of the profession also changed from its earlier concept of librarianship to library and information science. The library science manpower development programmes had to include the areas from traditional to modern subjects and the LIS education programmes have to be re-modeled to the contemporary requirements so as to suit the modern changing condition and demands. During this period more than 14 new departments came into existence: 19 universities have started further One-year course for master's degree in library science, About 6 universities programmes leading to Ph.D degree. In 661978, Department of LIS, University of Delhi is the only University in the country offering M.Phil course in library science

UGC panel on library and information science

LIS curriculum was significant as certain changes occurred in Indian Library Education regarding its changed components like information storage and retrieval, computer application etc. In 1973 and 1977 two national level seminars were organized by the Department of Library and Information Science of Delhi University, sponsored by the UGC. These seminars were on methods of teaching and evaluation in library science and LIS education. The panel made some recommendations on LIS courses and curriculum saying that the nomenclature of the department may be changed to reflect the changed curriculum. It also recommended a two year integrated programmes for MLIS, LIS department in universities as well as an independent status as other teaching departments, along with adequate infrastructure to offer research programmes.

\section{University schools offering LIS courses.}

$>$ Dr. H.S. Gour Vishwa Vidyalaya (Formerly University of Sagar)

$>$ Ravi Shankar University

$>$ Kashmir University

> Rani Durgavati University Jabalpur

$>$ Bhagalpur University (1971)

$>$ Bangalore University

> Madurai Kamaraj University, (1976)

$>$ S.V. University-Tirupati, (1974)

> Mokhanlal Sukhadia University, 1975 (Formerly Udaipur University)

$>$ Sambalpur University, (1976)
$>$ L.N. Mithila University

$>$ Calicut University (1979)

$>$ Gulbarga University (1979)

$>$ Saurastra University (1975)

$>$ Bhopal University (1976)

$>$ Jodhpur University (1974)

University upgraded their BLib.Sc. to M.Lib.Sc. Course In1970's

$>$ Aligarh Muslim University

$>$ Vikram University

$>$ Punjab University

$>$ Karnataka University

$>$ Mysore University

$>$ Calcutta University

$>$ Madras University

$>$ Bangalore University

$>$ Kerala University

$>$ Rajasthan University

$>$ Poona University

$>$ Osmania University

SNDT University

$>$ Burdwan University

Madurai Kamraj University

Lalit Narayan Mithila University

Shivaji University

Annamalai University

University Library schools affiliated to university, offering BLISc courses during the 1980's

Patna University

$>$ Sardar Patel University

Utkal University, 81- Bhubaneswar - Orissa

Jammu University

Himachal Pradesh University

> Mangalore University

> Bharati Dasan University

$>$ Kasi Vidyapeet

> Berhampur University - 1984

$>$ Ravindra Bharati University

> Guru Ghasi Das University

$>$ Bundel khand University

$>$ South Gujarat University

$>$ Manipur University

$>$ Jamia Islamia

> Tikal Maharashtra Vidyapeet

$>$ Pondicherry Central University

$>$ IGNOU

$>$ Dr.B.R. Ambedkar Open

$>$ University-Hyderabad

$>$ Agra University-Uttar Pradesh

$>$ Gujarat Vidyapeet 
International Journal of Trend in Scientific Research and Development (IJTSRD) @ www.ijtsrd.com eISSN: 2456-6470

University Library schools upgra
M.Lib. Sc.Course during 1980's
$>$ University of Jammu
$>$ Naga pur University
$>$ Kurukshetra University
$>$ Guru Nanak Dev University
$>$ Kashmir University
$>$ Dr. H.G. Gour Vishva Vidyalaya
$>$ APS University
$>$ Andhra University
$>$ Jadavpur University
$>$ S.V. University
$>$ M.S. University
$>$ Gujarat University
$>$ Gauhati University
$>$ Maratwada University
$>$ Ravi Shankar University
$>$ Sardar Patel University
$>$ Gulbarga University
$>$ Sambalpur University
$>$ Gourastra University
$>$ Guarat Vidyapeeta
$>$ University

During 1990-2000 Library and Information Science Education:

During this period, more than twenty schools running B.Lib.Sc. Course, were upgraded to offer M.Lib.Sc.Course. In this period major developments in the field of Library and Information Science education took place. More than $80 \%$ of Library and Information Science schools introduced two year integrated Library and Information Science course. A Two year integrated courses leading to M.Sc in Library and Information Science was also been introduced in three universities. University of Madras, Kuvempu University and Birla Institute of technology. They have introduced two year integrated course leading to M.Sc in Library and Information Science.

The following university Library and Information Science Schools started offering B.Lib Sc. in 1990's

$>$ North Gujarat University - 2 y. MLISc

$>$ Chitracut Gramodaya Vishvavidyalaya - MLISc- 1992, 93

$>$ Kalyani University - 1992-93

> Nagar wachanalya, Mahavidyalaya (Approved by Amravati University)

$>$ Uttar Maharashtra Vidya peet - 1992-93

> Makhanlal Chaturvedi University - 2 y MLIS - 1992

$>$ Bharktulla University - BLIS through correspondence

$>$ Jai Narayan University - 1994-95

$>$ Gandhigrama Rural Institute

$>$ Central Institute of LIS Hyderabad - 92-93

$>$ Nagarjuna University 2 y MLISc -1993-94

> Mahatma Gandhi University - MLISc 2 y, Kerala

$>$ Uttar Maharashtra Vidya Peet - Jalagam - BLIS - 1992 93

> Vidya sagar University West Bengal- 2 y MLISc
> Kamta plased Guru Bhasha Bharati - Jabalpur (Approved by R.D. Vishwa Vidyalaya - Jabalpur)

University LIS Schools started offering MLISc in 1990's

> Mangalore University started in1990

$>$ Amravati University started in 1993-94

$>$ B.R. Ambedkar University Agra in 1996-97

> Mohalal Sukhadia University in 1995-96

$>$ University of Calicut - 1994

> Sambalpur University started in 1995 M.Phil

$>$ Berhampur University started in 1995

$>$ IGNOU started in 1994

> Mekhanlal Chaturvedi National University- 1993

$>$ Bhavnagar University started in 1992

$>$ South Gujarat University started in1994

$>$ Madras University Department of LIS : 1995

During 2000-09 Library and Information Science Education : Many universities and academic institutions of Higher education started Bachelor and Master Degree courses in library and Information science Since the year 2000.

\section{Universities and Institutions are:}

$>$ Institute of Advanced Studies in Education - B.Lib Sc and M.Lib Sc.

$>$ Mizoram University - B.Lib Sc

$>$ Allahabad Agriculture Institute- UP, B.Lib Sc and M.Lib Sc nal

Karnataka State Open University - Karnataka, B.Lib. Sc

Growth of Ph.D theses in LIS

The following table shows that the number of doctoral degree awarded in this field of LIS starting from the year 1984 to 2015 . It is clear from the table that a total number of $6(18.18 \%)$ theses were awarded in the year 2012 and it was the maximum in terms of number of theses awarded during the period. Though growth rate differs from year to year and most of the cases only one thesis was awarded. In 1992 and 2014 , three theses were awarded respectively.

\begin{tabular}{|c|c|c|c|}
\hline S. No. & Year & No. of PhD theses & Percentage \\
\hline 1 & 1984 & 1 & 3.03 \\
\hline 2 & 1988 & 1 & 3.03 \\
\hline 3 & 1990 & 1 & 3.03 \\
\hline 4 & 1991 & 1 & 3.03 \\
\hline 5 & 1992 & 3 & 9.09 \\
\hline 6 & 1994 & 1 & 3.03 \\
\hline 7 & 1995 & 2 & 6.06 \\
\hline 8 & 2003 & 1 & 3.03 \\
\hline 9 & 2004 & 1 & 3.03 \\
\hline 10 & 2006 & 2 & 6.06 \\
\hline 11 & 2007 & 1 & 3.03 \\
\hline 12 & 2008 & 2 & 6.06 \\
\hline 13 & 2009 & 2 & 6.06 \\
\hline 14 & 2010 & 2 & 6.06 \\
\hline 15 & 2012 & 6 & 18.18 \\
\hline 16 & 2013 & 1 & 3.03 \\
\hline 17 & 2014 & 3 & 9.09 \\
\hline 18 & 2015 & 2 & 6.06 \\
\hline & & 33 & 100.00 \\
\hline
\end{tabular}

Growth of Ph.D theses 
Library and Information Science Education Levels:

To provide effective and efficient Library Services, a well qualified and capable manpower is required. The Educational and training facilities in LIS course offered at different levels in Karnataka state are: Certificate Course, Diploma Course, Bachelor's degree course in Library and Information Science, Masters Degree course in Library and Information Science Associateship course, M.Phil. And Ph.D Programme and Continuing Education programme in Distance Mode.

\section{Five Year Integrated Course in LIS:}

University of Calcutta introduces five year integrated course in Library \& Information Science in 2010 and becomes the first university to launch this course in Library and Inf.Sc. Qualification for this course was set at Higher Secondary in Arts / Science or Commerce. Launching of this course will force the learners to choose the LIS by choice and not by chance. It will again help the students to grasp and understand the contents for LIS in a better and exhaustive way.

\section{Present Status of LIS Education in India:}

India imparting Library and Information Science education departments in different levels a few departments and associations provide Certificate Courses in Library and Information Science (CLIS) and Diploma in Library and Information Science (DLIS). The others provide BLISc and MLISc courses. In most of the universities, the prerequisite for admission into the Bachelor or Master Degree course in Library and Information Science is $10+2+3$ years of education from any faculty (arts, science, commerce etc). The majority of the universities generally conduct two separate courses for the Bachelor's degree followed by the Master of Library and Information Science of one year (or two semesters) duration each. In recent years, some institutions have offered two years of integrated courses of four semester duration. The University of Calcutta went a step ahead and introduced five years integrated course in LIS with entry qualification as $10+2$.

UGC and ICSSR award scholarship to doctoral students. National Commission on Science and Technology, New Delhi. RRLF Raja Ram Mohan Roy Library Foundation (Calcutta) and ICSSR among others provide research Grants for nondoctoral research. NASSDOC once proposed to start from 1988 the Associate ship course. it course was shelved Later on National Centre for Science Information (NCS1) located at Bangalore provides an advanced one year training course in Information systems required to submit project report and dissertation in partial fulfillment of the courses. DESIDOC Defense Scientific Information and documentation Centre (DESIDOC) also provide JRF programme in Library and Information Science.

Most universities school Students of library and information science has the opportunity to develop at least some degree of specialization. Some may take advanced courses in particular library functions, such as reference work, while others may take courses related to a particular type of library, such as a course in medical librarianship or public librarianship or academic librarianship. In simple, there are many different courses available in LIS. It makes the professionals available to work at all levels of library irrespective of type, structure and function.
All programmes to educate librarians share certain characteristics. Programmes typically offer courses in the history of books and librarianship to give students a background in the profession's past. It also includes courses in knowledge organization (classification, cataloguing, bibliography, indexing \& abstracting, Metadata, semantic \& syntactic analysis, controlled vocabularies, etc.), collection development (acquisition), information seeking behaviors of users, search strategies, library services (dissemination of the acquired library materials, reference), and management of the collection (preservation \& conservation of documents). It also includes contents related to scholarly communication (bibliometrics, informatics' scientometrics, and web metrics), digital libraries and ICT.

\section{ICT in LIS Education:}

Technology is entering in a very big way to LIS where it has been used extensively to store and retrieve information in different forms and structures. This new dimension is reflected in the course structure of almost all universities that provides courses in LIS. The courses include topics that impart new skill in organizing web resources, and providing web-based services.

\section{Practical Exposure:}

All courses provide scope of practical knowledge rather than restricting to only theory. Even some universities make it compulsory for their learners to undergo some apprenticeship courses before practicing the librarianship.

\section{Conclusion}

Growth and development of a subject field are directly associated with the amount of research undertaken in that particular subject area and if the subject finds very few scholars at all, the subject is bound to die down. The Research state of library and information science in India by and large is good, but there is considerable need to improve both the academic and research state of the subject field across the country IS education in India has always stressed on professional obligation to keep informed the academic and professional developments through teaching and Research. LIS educators are constantly engaged in Developing their competency and specialization, dissemination of research through teaching and discovery of knowledge through research to its learners and researchers. The government of India has also Undertaken and announced a number of steps in this direction such as Information Technology Act (2000), E-Governance, Right to Information Act (2005), Library and Information Networks and Consortia, Establishment of Knowledge Commission, Knowledge Center and dramatic developments in computer and communication technologies including telecommunications. If the centre's of LIS studies in general and LIS educators in particular are to Continue to occupy a central position in the educational process, it is high time to revamp and reorient LIS education compatible to developed countries. It is the need of the hour for the LIS schools to produce qualitative problem solvers and effective information managers possessing a broad range of capabilities to meet the highest demand in the information sectors. "Education for Information" can provide ample scope to information professionals in a variety of academic, corporate and government sectors and meet the challenges of the new millennium. 
International Journal of Trend in Scientific Research and Development (IJTSRD) @ www.ijtsrd.com eISSN: 2456-6470

LIS as a subject is not concentrated in a particular belt of the country. The seventeen states and union territories which have been awarded a doctoral degree in LIS represent all most all the regions of the country. However, at the state

\section{References}

[1] DESIDOC Journal of Library \& Information Technology ,Vol. 30, No. 5, September 2010, pp. 3-8

[2] LIS Education in India: Challenges for Students and Professionals in the Digital Age P.K.Jain, Harvinder Kaur and Praveen Babbar Institute of Economic Growth, University of Delhi Enclave,

[3] http://shodhganga.inflibnet.ac.in/bitstream/10603/17 835/8/09_chapter\%203.pdf

[4] http://shodhganga.inflibnet.ac.in
[5] International Journal of Academic Research and Development Volume 3; Issue 2; March 2018

[6] Malaysian Journal of Library \& Information Science, Vol.8, no.2, Dec.2003: 1-17

[7] Asia-Pacific Conference on Library \& Information Education \& Practice, 2006

[8] http://www.netugc.com/library-and-informationscience-education-in-india

[9] DESIDOC Journal of Library \& Information Technology, Vol. 37, No. 6, November 2017

[10] SRELS Journal of Information Management, Vol 52(6), December 2015, p. 403-414

[11] International Research: Journal of Library \& Information Science | Vol.7 No.4 Dec., 2017 